\title{
BioTime acquires Geron's stem cell program
}

Geron's stem cell assets were given a new lease in early January when former CEO Tom Okarma, now heading a subsidiary of BioTime of Alameda, California, signed a definitive agreement for the latter to take control of the human embryonic stem cell (hESC) program. At the same time, the US Supreme Court ended a recent battle over hESC research when it declined to hear Sherley vs. Sebelius, a case that challenged federal funding for hESCs. James Thomson, professor of cell and regenerative biology at the University of Wisconsin in Madison, and the first to derive an hESC cell line in 1998, says, "Now there will be a way for Geron's work in this area to move forward," adding, "after years of controversy there is finally a reasonable policy for stem cell research."

As the first company to run a clinical trial using hESC-derived cells, Geron was once a flagship for stem cell research translation. The phase 1 trial had treated five acute spinal cord injury patients with its oligodendrocyte product, OPC1, when Geron discontinued its program in November 2011 (Nat. Biotechnol. 30, 12-13, 2012). At that time, the company shifted its business focus to telomerase-based cancer drugs, and although Geron indicated it was seeking partners for the stem cell program, there were no takers, until Thomas Okarma, who left Geron when it shelved its hESC program, and BioTime's Michael West, also a former Geron $\mathrm{CEO}$, approached the company. Last November, they struck a deal. West hired Okarma to head a new subsidiary of BioTime-BioTime Acquisition (or BAC) - to incorporate Geron's stem cell assets.

According to the terms of the deal, Geron will contribute intellectual property and other assets, including the phase 1 clinical trial, to BAC. BioTime will contribute $\$ 5$ million in cash, common shares, certain rights to patents and technologies, and will also pay royalties to Geron on sales of any commercialized products. A private, unnamed investor will also make \$5-million equity investments in BAC and also in BioTime in conjunction with the transaction.

"What we really have here is a startup, or restartup, of Geron," Okarma says. Although an immediate goal is to resume the clinical trial and integrate the two companies' research, it will take about six months to assess Geron's assets-cell lines, contracts and good manufacturing practice material-to see if they are viable and thus whether the deal can be finalized. Depending on what BAC researchers find, the hope is to move earlier-stage programs forward, including research on cardiomyocytes and chondrocytes for disc degeneration, as well as to extend the oligodendrocyte-acute spinal cord

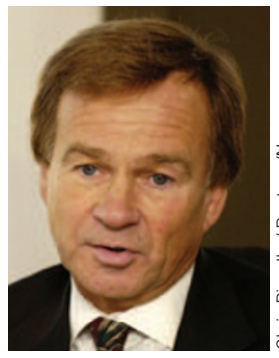

Thomas Okarma will now forge ahead with his former company's studies.

other possible indications.

"Geron invested an enormous amount of resources into that OPC1 program, and it seems promising," says Paul Knoepfler associate professor of cell biology and human anatomy at University of California, Davis. Although Thomson sees an opportunity for BioTime now to accrue some early successes with its combined portfolio, he says that paralysis is "a remarkably difficult target," in contrast to macular degeneration. In the meantime, phase 1 and 2 trials using hESC-derived cells for two types of macular degeneration are ongoing, sponsored by Advanced Cell Technology, of Santa Monica, California, which West founded in 1999.

Although it is too early to know what programs will be viable, Okarma is speaking with former employees and collaborators, and consolidating intellectual property, with the hope of restarting research into Geron's five cell types and integrating it into BioTime's stem cell subsidiaries. "Ultimately, we want to share expertise in the company and build a universe of companies that are cooperative, not competitive, and get products into patients," Okarma says. He will be looking for new sources of funding in South America and Asia, and to conduct trials abroad as well as in the US. Vicki Brower New York

\section{Brüstle patent holds up in Germany}

In Europe, the German Federal Court of Justice gave a final verdict on November 27 in the Greenpeace vs. Brüstle case, indicating that the contested Oliver Brüstle patent, which covers technology for extracting human embryonic stem cells (hESCs) at the blastocyst stage, was valid. The decision follows a controversial judgment by the Court of Justice of the European Union (CJEU) in October 2011 (Nat. Biotechnol. 29, 1057-1059, 2011), stating that stem cell processes based on the use of embryos are not patentable, which caused considerable outcry in the biotech community. Critically, however, the CJEU ruling only covered the patentability of technologies describing hESCs derived by means of embryo destruction; decisions on the patentability of hESC technologies that derive cells at the blastocyst stage were delegated to the national courts, prompting the recent German federal court case.

Julian Hitchcock, counsel at the law firm Lawford Davies Denoon in London, believes the recent ruling points to a more liberal regime, in Germany at least. "All other things aside, if you didn't destroy an embryo it should be possible to get a patent," Hitchcock says. This should encourage investors who were deterred by the CJEU ruling. "Given the very small amount of discretion that was given to the German court by the CJEU, it has been exercised in a favorable way." Paul Chapman, partner at the London law firm Marks \& Clerk agreed that "those who want to protect inventions relating to human embryonic stem cells in Europe now have a glimmer of hope."

The October 2011 judgment by the CJEU had an impact on the patenting regime, with both the European Patent Office and UK Intellectual Property Office putting in place guidelines prohibiting patents on stem cells derived from blastocysts. Based on those guidelines, in August 2012, International Stem Cell of Carlsbad, California, was refused a patent by the UK Intellectual Property Office on its technique for activating oocytes through parthenogenesis to produce human embryonic stem cells. The UK Patent Office found on the basis of the CJEU's Brüstle ruling that a parthenogenetically derived structure is analogous to the blastocyst stage of normal embryonic development and did fall within the definition of a human embryo. International Stem Cell is now appealing the decision and the German ruling is likely to influence the pending hearing. Chapman believes the guidelines may be revised in light of the German court's decision.

Hitchcock noted that although the ruling of the German Court opens up the prospect of patents on embryonic stem cell products that did not involve destruction of an embryo, it leaves in place the CJEU's 'totipotency rule' which states that any cell line arising from an embryonic stem cell that involved the destruction of an embryo cannot be patented. "This holds, no matter how far downstream [a product] is," Hitchcock said. Nuala Moran London 